Editorial

\title{
Luz e memória
}

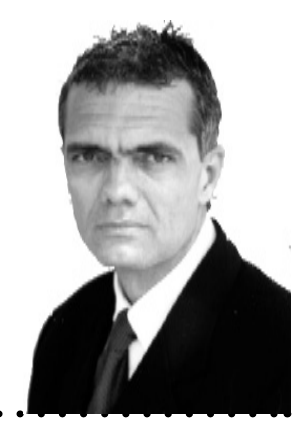

Marco Antonio Guimarães da Silva marco@atlanticaedu.com.br

A moderna teoria quântica, desenvolvida no inicio do século XX, estabelece que a luz é composta por fótons e que são pequenos feixes de onda de luz, cada um deles com energia proporcional à freqüência. Ainda que já tenha sido aluno do curso de física, na virada dos anos 60 , não irei avançar por esse caminho, porque interessa-me aqui discutir um outro aspecto da luz.

No meio cinematográfico e teatral, a luz pode sofrer adaptaçóes circunstanciadas à necessidade do momento, para expressar angústias, provocar medos, acentuar a tensão e dar cores a emoção.

$\mathrm{Na}$ pintura, os impressionistas - leia-se Edouard Manet (1832-1883), Claude Monet (1840-1926) e Edgard Degas (1834-1917) - fisgavam a luminosidade de um determinado momento e, em determinadas condiçóes, a transportavam para as telas.

$\mathrm{Na}$ literatura, alguns autores pictoricamente captam os fatos em estado de duração e contextualizam luzes e cores em suas obras. A pintura em prosa de Eça de Queiroz adquire excepcional qualidade artística nas páginas de alguns de seus romances e escritos. Em Egito, Notas de Viagem, há uma bela passagem: "As verduras do Delta, que se estendem nos distantes horizontes, sob a pulverização faiscante da luz" ou a "a luz que caía, magnífica, sobre tudo isso, tão forte, tão viva que parece pousar sobre as coisas como uma espécie de névoa luminosa". Esse sentido pictórico impressionista se manifesta também em Primo Basilio, quando descreve o passeio de Luísa e do primo, ao Lumiar, em um dia caloroso de julho: "Os velhos estores do coupé corrido eram de seda vermelha e a luz que os atravessava envolvia-a em um tom cor de rosa e quente, os seus lábios tinham um escarlate, a lisura sã de uma pétala de rosa e ao canto do olho um ponto de luz movia-se em um fluido doce". Para os que se interessarem pelo tema, sugiro leitura de Emile Zola, que também, magistralmente, ilumina e dá cor aos seus textos.

Essa mesma luz, aliciada pela literatura, pelo teatro e pela pintura, pode ser um poderoso agente pessoal, que nos leva a viajar no espaço e no tempo e a desfrutar belos momentos.

Acredito que quase todos nós já percebemos que os dias apresentam uma luminosidade e uma cor que variam com os lugares e com a época do ano. Em determinados momentos, a percepção sentida pelas cores do dia ou da noite nos remetem a uma aura de extrema felicidade.

Essa percepção, segundo Bergson (Matéria e Memória), contém uma imagem material referida a uma ação possível; ela é espacial, mas também se situa no tempo, porque não há percepçáo que não se situe em um momento de nossa vida.

Para Bergson, a vida psíquica se define como duração e se manifesta através da memória que capta o movimento da vida como unidade temporal. As imagens ou imagem que percebemos e idealizamos como geradoras de felicidade e prazer, no presente caso, nos são dadas com as luzes e cores do dia que combinam signos e elementos e que subliminarmente estão em nossa memória.

A grande questáo que se coloca aqui estaria em conseguir uma resposta para a seguinte questão: Por que, tantas vezes, a luz de terras alhures nos sensibiliza mais e nos oferta mais prazer? Por que, no lugar onde vivemos, não conseguimos essa sensação de elevação, o alcance do chamado estágio alfa? Estariam as minhas recordaçóes, convivendo em uma penumbra obscura e profunda, a impedir que o passado, onde o cotidiano era de felicidade e paz, se prolongue até o presente e seja parte de minha memória e se exteriorize quando necessário?

Não encontraríamos na concepção bergsoniana as nossas respostas. Muitíssimas vezes, pude sentir e perceber a energia e a beleza, transmitidas pela luz de um lugar, sem que jamais tivesse qualquer relação prévia com aquele lugar; a percepção daquela sensação não estava situada em nenhum momento de minha vida.

Coincidência ou não, os dissabores e a insegurança que nos cercam nessa nossa terra, por mim tantas vezes levantadas em outros editoriais, são, com certeza, as combinaçóes que me impedem de ter o mesmo prazer perceptivo, quase que sagrado, que a luz e as cores dos dias podem nos oferecer.

Se você consegue, aqui nesse país, a dose de abstraçáo que o permita entrar em comunhão com o momento mágico oferecido pela conjunção de luz e cores do dia, levante as mãos para os céus e dê graças ao seu bom Deus, seja lá qual for ele. 